\title{
ATTRIBUTION AND SELF-CONCEPT AS PREDICTORS OF CAREER MATURITY AMONG LECTURERS IN TERTIARY INSTITUTIONS OF KANO STATE, NIGERIA
}

\author{
YUSUF MUSA KIBIYA, PhD ${ }_{M c a s s o n, \text { Mnisep, }}$ AND BILKISU UMAR ZANDAM ${ }_{M c a s s o n}$
}

\begin{abstract}
This study examined how attribution and self-concept predict career maturity of lecturers in tertiary institutions of Kano State. The study adopted correlation method with a sample of 312 out of 1,653 tertiary institutions' teachers. Four hypotheses were formulated and tested through the use of Pearson Product Moment Correlation Coefficient and Standard Multiple Regressions. The result of the study posits that there is a significant relationship among attribution, self-concept and career maturity of lecturers in tertiary institutions of Kano State. That is to say attribution and self-concept of the teachers predict their career maturity. Among the independent variables, self-concept with a higher beta value of 0.631 serves as a major contributor toward predicting career maturity of the teachers in tertiary institutions of Kano State. This entails that Kano State Ministry for Higher Education should motivate her teachers to develop positive self-concept as well as internal attribution towards their career. Other recommendations were proffered for practical application, especially provision of necessary facilities to make the working environment friendlier.
\end{abstract}

Key words: Self-concept, Attribution, Career maturity, Tertiary institutions, Lecturers.

\section{Introduction}

Almost every event or behaviour has causes of determination. That is to say people have their process of determining causes of events. At one time or another, a person may think that on someone did something and he might likely understand or not understand the reason for doing that. In essence either the person did understand or did not, there should be some causes to that activity or event (Goldstein, 1994). People in their life strive to have something or fulfill their motives either in success or in failure, in the process of doing this, they normally attribute their performance to a certain cause. With this statement, one can understand that people make attribution in order to help in understanding as well as predict behaviour. In essence, attribution as Weiner (1980) puts it is a synonym for explanation, that is to say, its concern is mainly on how people explain things. As explained attribution has been divided into two main types based on the fact that it is assigned to the cause of a certain behavior. These types (internal and external attributions) depend on the consistency, distinctiveness as well as consensus (Nairne, 2006).

A person's feeling about oneself is referred to self-concept (Salawu and Isah, 2005). Guay, Larose and Biovin (2004) explain that self-concept is a specific domain that evaluates self through considering past and present experiences thereby building the future anticipation. This shows that an individual person makes self-evaluation in so many domains comprising social, physical, academic, athletic, psychological appearances etc (Elosua and Muniz, 2010). Likewise Waugh (2000) and Marsh (2009) explained that self-concept is the total picture of a person referred to him/her through perception and establishing intra and inter personal relationships. That is to say self-concept is a composite of the individual's traits, feelings, 
values and thoughts. It is also a conceptual and mental understanding of oneself with regard to a person's function in an environment.

Considering the series of definitions above, one can consider the position that people see themselves in different ways in which they perceive and believe themselves in relation to their success or failure about their action and identity. This notion entails two types of selfconcept as put by Swann, Rentfrow and Guinn (2009), Tafarodi and Swann (2001) and Wilson (2009) that some people are having positive self-concept which makes them feel competent as well as capable enough in undertaking certain tasks in their life. Their actions to other people demonstrate positive feelings, and in turn others react positively to their actions validating those feelings effectively. Others with negative self-concept lack confidence in their abilities, they feel inferior and defeated as such their feelings affect their actions in their environment and in turn other people may react to them based on their actions negatively thereby culminating negative self-feeling (Strongman, 2006).

Career maturity is defined as individual's ability to make appropriate career choice, including general awareness of what is required to make career decisions and the degree to which one's choice is realistic and consistence over time (Lal, 2013). In another way, career maturity is seen as a concept consisting readiness, attitude and competency to cope effectively with career development tasks. Career maturity is an important aspect of human life that attracts so many efforts in trying to develop and ensure its effectiveness. Savickas (1984) defined career maturity as readiness to cope with career developmental tasks. According to McConnell (2011), Career maturity is defined as what people believe to be true about them. This posits that Career is referred to sequence of occupations, jobs and positions occupied during individual's working life (Ogbochuku, 2000). It is an experience concerning one's life-long activities (Akume, 2010).

In another way, Ahmadu and Afu (2010) defined Career as the totality of work one does and positions in a life time. In another postulation, Career maturity is seen as person's selfperceptions that are formed through experience with and interpretations of one's environment (O'mara, Marsh, Craven and Debus, 2006). With the explanation above, it is clear that career maturity is seen as a measure of readiness to make career decisions and adjustments on the basis of one's aptitudes, personality traits and knowledge of career decision-making. Bukoye (2000) maintains that attention should be focused on the individual's acquisition of skills to make effective adjustment resulting to the consequent career development which is the ultimate aim in career maturity. Super (1957) insists that career development follows the trait of individual's human development which is spread on stages. He further argues that the personality developmental trend of an individual goes hand in hand with his career development, and accordingly career is seen as all the roles played by a person throughout the lifetime. In a nutshell, all the definitions of career maturity can be regarded as what Dybwad (2008) presented that an individual person refers to career maturity as a place reached on the continuum of career development starting from exploration to decline. Thus, the main problem of this study was to examine whether attribution and self-concept predict the career maturity of lecturers in tertiary institutions of Kano State. 


\section{Research question}

1. Does relationship exist between attribution and self-concept of lecturers in tertiary institutions of Kano State?

2. Is there any relationship between attribution and career maturity of lecturers in tertiary institutions of Kano State?

3. What is the relationship between self-concept and career maturity of lecturers in tertiary institutions of Kano State?

4. Do relationships exist in attribution, self-concept and career maturity of lecturers in tertiary institutions of Kano State?

\section{Objectives of the Research}

1. To find out the relationship between attribution and self-concept of lecturers in tertiary institutions of Kano State.

2. To see if there is any relationship between attribution and career maturity of lecturers in tertiary institutions of Kano State.

3. To examine the relationship between self-concept and career maturity of lecturers in tertiary institutions of Kano State.

4. To find out the relationships in attribution, self-concept and career maturity of lecturers in tertiary institutions of Kano State.

\section{Hypotheses of the research}

1. There is no significant relationship between attribution and self-concept of lecturers in tertiary institutions of Kano State.

2. There is no significant relationship between attribution and career maturity of lecturers in tertiary institutions of Kano State.

3. There is no significant relationship between self-concept and career maturity of lecturers in tertiary institutions of Kano State.

4. There is no significant relationship in attribution, self-concept and career maturity of lecturers in tertiary institutions of Kano State.

\section{Methodology}

Correlational research design was used in this investigation because it was a research method which attempted to discover or establish the existence of relationship between two or more variables. Best and Kahn (2006) posit that correlational research is a method of examining the interrelationship between independent and dependent variables. Kouting (2004) reiterates that correlational study gives emphasis on establishing how close the links are between the variables under study. In this study, attribution and self-concept were the independent variables while career maturity was the dependent variable.

The population of this study was the entire lecturers in Kano State tertiary institutions with a total staff strength of 1,653. Using Slovin (2013) formula for determining sample size, the 
research used 312 lecturers as sample that were randomly selected through simple random sampling procedure.

\section{Study Instruments}

The instruments used in the study were three

Tambawal (2001) adopted version of Self-Other Motivation scale measuring attribution concerning the happenings around individual. The instrument has both face and content validity with reliability value of 0.88 .

Tambawal (2001) adopted version of Adolescent Personal Data Inventory for measuring Self-concept of individual with face and content validity as well as reliability value of 0.87 .

Tambawal (2001) adopted version of career maturity inventory attitude scale for measuring career maturity of people. The scale has face and content validity with reliability value of 0.72 .

\section{Results}

Four hypotheses were postulated in this study and tested with appropriate statistical techniques that justified the nature of the cause of examination. Hypotheses $1-3$ were tested with the use of Pearson Product Moment Correlation Coefficient (Pearson ' $r$ ') at level of significance of 0.05 as shown below; and hypothesis 4 was tested by the use of multiple regression statistical analysis.

$\mathrm{H}_{\mathrm{o} 1}$ : There is no significant relationship between attribution and self-concept of lecturers in state tertiary institutions of Kano State.

In order to test this hypothesis, data on career interest and career maturity from the respondents were collected and subjected to Pearson Product Moment Correlation Coefficient Statistics.

Table 1: $\quad$ Summary of Pearson ' $r$ ' showing relationship between Attribution and Self-concept of Lecturers in tertiary institutions of Kano State

\begin{tabular}{lcccccc}
\hline Variables & No. & Mean & Std & $\begin{array}{l}\text { Cal } \\
\text { r-value }\end{array}$ & P & Remarks \\
\hline Attribution & 312 & 35.40 & 4.50 & 0.541 & .000 & Rejected \\
Self-concept & 312 & 36.81 & 5.12 & & & \\
\hline
\end{tabular}

Table 1 above shows that the calculated $r$-value is 0.541 . Since the calculated value is greater than the P-value, therefore hypothesis one (1) is rejected and it shows that there is positive significant relationship between the Attribution and Self-concept of Lecturers in tertiary institutions of Kano State. 
$\mathrm{Ho}_{2}$ : There is no significant relationship between attribution and career interest of Lecturers in state owned tertiary institutions of Kano State.

In testing this hypothesis, responses of the subjects (lecturers) on career interest and SelfConcept were both collated and subjected to Pearson Product Moment Correlation Coefficient as explained below.

Table 2: $\quad$ Summary of Pearson ' $r$ ' showing relationship between Attribution and Career maturity of Lecturers in tertiary institutions of Kano State

\begin{tabular}{|c|c|c|c|c|c|c|}
\hline Variables & No. Mean & \multicolumn{2}{|c|}{ Std Cal r-value I } & \multicolumn{2}{|c|}{ Remarks } & \\
\hline Attribution & 312 & 35.40 & 4.50 & 0.796 & .000 & Rejected \\
\hline Career maturity & 312 & 34.17 & 4.27 & & & \\
\hline
\end{tabular}

Table 2 above shows that the calculated ' $r$ ' is 0.796 which is greater than the P-value therefore hypothesis two (2) is rejected. Hence there is a positive as well as significant relationship between attribution and career maturity of Lecturers in tertiary institutions of Kano State.

Ho3: There is no significant relationship between self-concept and career interest of Lecturers in tertiary institutions of Kano State.

In testing this hypothesis, responses of the subjects (lecturers) on self-concept and career maturity were collected and subjected to Pearson Product Moment Correlation Coefficient statistic as explained below.

Table 3: $\quad$ Summary of Pearson ' $r$ ' showing relationship between Self-concept and Career maturity of Lecturers in tertiary institutions of Kano State

\begin{tabular}{lcccccc}
\hline Variables & No. & mean & Std & $\begin{array}{c}\text { Calr- } \\
\text { value }\end{array}$ & P & Remarks \\
Self-concept & 312 & 33.64 & 3.87 & 0.517 & .000 & Rejected \\
Career maturity & 312 & 34.17 & 4.27 & & & \\
\hline
\end{tabular}

Table 3 above shows that the calculated ' $r$ ' 0.517 which is greater than the P-value therefore hypothesis three (3) is rejected. Hence there is a significant relationship between self-concept and career maturity of Lecturers in tertiary institutions of Kano State.

$\mathrm{H}_{04}$ : There is no significant relationship among attribution, self-concept and career maturity of lecturers in tertiary institutions of Kano state.

In testing this hypothesis, responses on the three variables was subjected to statistical analysis of standard multiple regressions in order to ascertain the existence as well as extent of the relationship among the variables as table 4 indicates. 
Table 4: Standard multiple regression showing relationship in attribution, selfconcept, and career maturity of lecturers in tertiary institutions of Kano State

Multiple R (Adjusted) $\quad .771$

Multiple R2 (Adjusted) $\quad .594$

Standard Error Estimate $\quad 2.704$

\begin{tabular}{llllll}
$\begin{array}{l}\text { Parameters } \\
\text { (Constant) }\end{array}$ & $\mathrm{B}$ & $\mathrm{Std}$ & Beta & $\mathrm{t}$ & $\mathrm{P}$ \\
\hline Attribution & 0.205 & 4.50 & 0.218 & 5.052 & .000 \\
Self-concept & 0.521 & 5.12 & 0.631 & 14.634 & .000 \\
\hline
\end{tabular}

Table 4 above shows that relationship exists in attribution, self-concept and career maturity of the lecturers in tertiary institutions of Kano State. This is evident in comparing the beta values of each independent variable. Attribution has a beta value of 0.218 and Self-concept has a beta value of 0.631 . This means that self-concept with a greater beta value of 0.631 makes the strongest as well as unique contribution in explaining the dependent variable which is career maturity.

\section{Discussion of the Findings}

The result of the study indicated that there was a significant relationship between Attribution and Self-concept of Lecturers in tertiary institutions of Kano State. This assertion was in line with the findings of many researches conducted in many places. Some of these included studies undertaken by Liu (1996), Matovu (2011), Awan, Ghazala and Anjum (2011) where all the researches revealed that significant relationship existed between self-concept and attribution. Studies conducted by Gordon (1997), Marsh and Martin (2011), Jackman, Wilson, Seaton and Craven (2011) as well as that of Lee and Jessica (1992) established that relationship existed between self-concept and attribution of an individual. Other researches that supported the present findings included studies conducted by Banks and Woolfson (2008), Kiamanesh (2004), Duval and Silvia (2002), Alpine and Shanks (2009), Scholl (2002), Brounstein, Holahan and Dreyden (2006) and Smart and Pascarella (1986) in which all the results of the studies posited a significant relationship between the self-concept of individual and his/her attribution. Taking into consideration that the computed results of the present study was widely supported by many researches; the present researcher deduced that self-concept and attribution of lecturers in tertiary institutions of Kano State are interrelated.

Hypothesis two revealed that there was no significant relationship between attribution and career maturity of lecturers in tertiary institutions of Kano State. The finding of the study indicated a positive relationship existing between attribution and career maturity of lecturers in tertiary institutions of Kano State. This result was in support of other findings by Abdullahi (2011), Wu (1998), Walker and Sorce (2009), Manuele (1984), Millet (2005) and Sandra (1998). In all the studies, it was revealed that there were significant relationships 
between attribution (Self-Other Motivation) and Career Maturity. This result was also in line with the findings of Patton, Butnaru and Creed (2004) which posited that individuals with internal self- other motivation (attribution) tended to display maturity in their careers. The findings of this study also supported Tambawal (2001) who upheld that persons with internal self-other motivations perceived all kinds of development positively. Therefore, the result indicated that to enhance career development of lecturers in tertiary institutions of Kano State, one needed to develop their attributions through various techniques in order to assist them internally as well as externally. This result was in line with the findings of Sara (2010), Nweza (1988), Ijeoma and Omotunde (2009), Abubakar (2010), Sandra (1992), Almisky, Bakar and Mohammed (2009) and Nandawa and Asawa (2007). The contributions of these findings was also in line with the studies of Uba and Olaniyi (1990) and Yaish and KatzGerro (2003) who found that there was correlation between career maturity and attribution of male and female individuals. Therefore it was clear that in choosing a career, according to the result of this study, attributional disposition played a significant role since both male and female individuals followed the same way.

Hypothesis four revealed that there was no significant relationship between attributions, selfconcept and career maturity of lecturers in tertiary institutions of Kano state. The finding of the study indicated that there was positive relationship between attribution, self-concept and career maturity of lecturers in tertiary institutions of Kano State. This present result also supported many findings some of which included Tambawal (2001), Mize (2005), Hirschi and Lage (2008), Mubiana (2010), Sneva (2011) and Kostko (2007). In all these studies, it was revealed that there was significant relationships among attribution, self-concept and career maturity of an individual. This result also confirmed the findings of Prideaux and Creed (2001), Forgarty and Bayne (2008), Ignatius (2012), Wigfold, Battle, Keller and Eccles (2000), Lau, Khan, Abdullahi and Chew (2011) which reaffirmed that individuals with positive self-concept normally displayed maturity in decision making in terms of career development. Therefore all the results showed that to enhance career development of lecturers in tertiary institutions of Kano State, the Ministry for Higher Education needed to develop their personality through various techniques in order to motivate the lecturers internally.

\section{Recommendations}

Looking at the results and findings of this study, the following recommendations can be put into place for the psychological preparation of teachers in tertiary institutions in Kano state, and for the general development of the institutions and nation at large.

1. To prepare teachers in tertiary institutions there is need for the state Ministry for Higher Education to avail all avenues of developing attribution and self-concept of the lecturers. This can be done through organizing workshops, seminars, trainings and other physical motivating measures like prompt payment of salary as well as other entitlements.

2. Non-Governmental organizations should assist in developing the attribution and career maturity of the lecturers thereby making all the tertiary institutions academically as well as physically conducive through procurement of all necessary 
facilities especially information and communication technology facilities. Provision of good office accommodation and recreational facilities which can make an environment physically conducive. This will make the environment friendly and can boost the preparation of the teachers thereby maximizing their output.

3. The self-concept and career maturity of the lecturers should be developed in order to make the teachers internally motivated through the provision of soft loans, career standard and other regulatory measures of the teaching profession which will also make them fully prepared in order to face the challenges of rigorous training and research in the higher institutions. This will lead the teachers to develop their selfesteem positively.

4. Teachers in tertiary institutions of Kano State should be assisted to develop physical, personal, psychological as well as academic construct of their working environment. This can be done through effective evaluation system and self- reporting procedure to ascertain the level of their performance. With this, the attribution, self-concept and career maturity of the teachers would be developed.

\section{Conclusion}

Considering the findings and discussion of the results of this study, it is evident that vocational adjustment (career maturity) of teachers in tertiary institutions of Kano state is affected by certain variables, these variables can be personal, psychological as well as physical. The variables may include, among other things, physical environment of the teachers' places of work, timely training; seminars and workshops, settlement of due entitlements, soft loans, vocational adjustment etc.

\section{References}

Abdullahi, O, E, (2011). Relationship among achievement motivation, self-esteem, locus of control and academic performance of Nigerian university students. A paper presented at Department of Educational Foundation University of Ilorin.

Abubakar, B. (2010). Relationship among social economic status, gender, self-concept and vocational aspiration of senior secondary school students in Sokoto. Unpublished M. Ed Dissertation. Usmanu Danfodiyo University, Sokoto.

Ahmad, J; Ghazali, M. and Hassan A. (2011). The Relationship Between Self-concept and Response towards Student's academic achievement among Students leaders in University Putra Malaysia.International Journal of Instruction, 4 (2).

Ahmadu, Y. and Afu, M. O. (2010). Students' Perception of factors that determine Career Choice Strategies and Problems of Career Counselling in Secondary Schools in Gwagwalada Area Council of FCT-Abuja. The Counsellor Journal of Counselling Association of Nigeria (CASSON).28. 
Ahsan, N, Abdullah, Z.; Fie, D. Y. G. and Alam, S. S. (2009). A Study of Job Stress on Job Satisfaction among University Staff in Malaysia: Empirical Study. European Journal of Social Sciences. 8 (1).

Akume, G.T. (2010).Personality Development and Vocational Guidance Makurdi: Destiny Ventures.

Almiskry, A.S.; Bakar, A.R. and Mohamed, O. (2009).Gender Difference and Career Interest among undergraduates: Implication for career choice. European Journal of Scientific Research. Alpine, S.K. and Shanks, A. (2009). Self-concept and attribution about other women in Women with a history of childhood sexual abuse. Journal of Clinical Psychology, 17(3): 196-210.

Awan, R.; Ghazala, N. and Anjum, N. (2011). A study of relationship between achievement motivation, academic self-concept and achievement in English and Mathematics at Secondary Schools Open Journal System, 4 (3).

Banks, M. and Woolfson, L. (2008). Why do students think they fail? The relationship between attributions and academic self-perceptions. British Journal of Special Education. 35 (1).

Best, J.W and Kahn, J.V (2006). Research in Education.(Tenth Edition). New Delhi prentice hall of India private limited.

Brounstein, P. J, Holahan, W. and Dreyden, J. (2006). Change in Self-concept and Attributional Styles Among Academically Gifted Adolescents. Journal of Applied Social Psychology, 21: 198-218.

Bruinsma, M. and Ahmed, W. (2006): A Structural model of Self-concept, Autonomous motivation and Academic performance in Cross-cultural perspective. Electronic Journal of Reseach in Educational Psychology, 4 (3): No.10.

Bukoye, R.O. (2000). Career Guidance for Secondary Schools students. Ibadan: Bololan Publishers.

Duval, T. S. and Silvia, P. J. (2002).Self- Awareness, probability of improvement and the Self-serving bias Journal of personality and Social Psychology. 82 (1): 49-61.

Dyabwad, T. (2008).Career Maturity: Contribution to its Construct Validity. Unpublished $\mathrm{PhD}$ Thesis University of Norway

Goldstein, E. B. (1994). Psychology. California: Brooks/Cole Publishing Company.

Gordon, D. (1997). The relationship among academic self-concept, academic achievement, and persistence with self-attribution, study habits, and perceived school environment. Unpublished PhD. Thesis. http//www.worldcat.org. 
Guay, F.; Larose, S. and Boivin, M. (2004). Academic Self-concept and Educational Attainment Level: A Ten-year Longitudinal study. www.elitetypesetting.com

Hayes, N. (1998). Foundations of Psychology. An Introduction Text.(Second Edition). London: Thomas Nelson.

Hirschi, A. and Lage, D. (2008). Using Accuracy of Self-Estimated interest-type as a sign of Career choice readiness in Career Assessment of Secondary students. Journal of Career Assessment, 16(3): 310-325.

Ignatius, N. U. (2012). A Study of the relationship between levels of Career maturity and Self-concept in the Career development of College undergraduate students. Unpublished PhD. Thesis. Marquette University.

Ijeoma, A. H. and Omotunde, E. E. (2009). Vocational Interest, Counselling, Scio-economic Status and Age as Correlates of Reentry of Girls in to Schools in Edo State.Edo Journal of Counselling. 2 (1).

Jackman, K.; Wilson, I.. G.; Seaton, M. and Craven, R. G. (2011). Big fish in a Big Pond: a study of academic self-concept in first year medical students. http://www.biomedcentral.com/1472-6920/11/48.

Kiamanesh, A. R. (2004). Self-concept, Home Background, Attitude, Attribution and their effect on Iranian Students' Science achievement.www.Wikipedia.org/wiki/self-concept.

Kostko, O. (2007).Career Decision making Self-Efficacy among High School Students in Selected public and private Schools in Bangkok, Thailand. Unpublished PhD. Thesis, Assumption University of Thailand.

Lal, K. (2013). Career Maturity in Relation to level of aspiration in Adolescent. American International Journal of Research in Humanities, Arts and Social Sciences. 5 (1): 113118.

Larson, L. M. and Borgen, F. H. (2006).Do personality Traits contribute to Vocational SelfEfficacy? Journal of Career Assessment, 14: 295.

Lau, P; Khan, K;Abdullahi, A. and Chew, F. (2011). The Effectiveness of Career Exploration program for High School. Journal of International Conference on Humanities, Society and Culture, 20.

Lee, L. and Jessica, K. (1992).Self-concept and attribution pattern of science and arts students in Honk Kong. Unpublished Master of Social Science dissertation. University of Hong Kong. Liu, Q. (1996).Role of academic attribution and academic self-concept in academic achievement: A path analysis. Unpublished PhD. Thesis University of Miami. 
Manuele, C. (1984). Modifying Vocational maturity in adults with delayed career development. Vocational Guidance Quarterly, 101-102.

Marsh, H. W. and Craven, R. G. (2000).Reciprocal effects of Self-concept and performance from a multidimensional perspective. $w w w$.wikipedia.org/wiki.self-concept.

Marsh, H. W. and Martin, A. J. (2011). Academic self-concept and academic achievement: Relation and causal ordering, British Journal of Educational Psychology. 81: 59-77.

Marsh, H. W. (2009). Self-concept, Research and Practice: Advances for the New Millennium. Collected papers of the inaugural Self-concept enhancement and learning facilitation (SELF) Research Centre International Conference, Sydney.

Matovu, M. (2011).Academic Self-concept and Academic achievement among University Students. International Online Journal of Educational Sciences, 4 (1): 107-116.

McConnell, A. R. (2011). The Multiple Self-Aspect Framework: Self-concept Representation and Its Implications. Personality and Social Psychology Review. 15 (1): 3-27.

Mize, J. B. (2005).Relationships of Career Decision-Making and Self-esteem for College Students and Athletes. Unpublished M. Sc. Dissertation Georgia Southern University.

Mubiana, P. B. (2010). Career maturity, Career knowledge, and Self- knowledge among Psychology Honours Students: An Exploratory Study. Unpublished M. Ed Dissertation, University of Pretoria.

Nairne, J. S. (2006).Psychology.(Fourth Edition).U. S. A: Thomson Corporation.

Nandwana, S. and Asawa, N. (2007). Vocational Interest of High and Low Creative Adolescent. Journal of Social Sciences. 14 (2).

Nathan, R. and Hill, L. (2006). Career Counselling. (Second Edition). London: SAGE Publications Limited.

Nayak, N. (2005). Mental Health and Adjustment of Secondary school Teachers influencing Development of Self-concept in Teachers. Unpublished PhD. Thesis University of Utkal.

Nwezeh, C. W. (1998). Factors affecting the Vocational Aspiration of Students of Oyo State College of Arts and Science, Ile-Ife Nigerian Journal of Counselling and Development, 2 (1).

O’Mara, A. J; Marsh, H. W.; Craven, R. G. and Debus, R. L. (2006). Do Self-concept Interventions Make a Differences? A Synergistic Blend of Construct Validation and MetaAnalysis. Educatinal Psychologist, 41(3): 181-206. 
Prideaux, L. and Creed. P. A. (2001). Career maturity, Career decision-making Self-Efficacy and Career indecision: A review of the accrued evidence. Australian Journal of Career Development.10 (2).

Salawu, A.A. and Isah, A. M. (2005). Basic Concepts in Educational Psychology. A Handbook for Students in Colleges of Education and Universities. Kaduna: Nasara Press Limited.

Sandra, K. (1992). Life Cycle and Career Development. Adult Learning and Vocational Education Digest (119).

Sara, S. S. (2010). Effect of learning style on Career Preferences of Senior Secondary School Students in Jigawa State, Nigeria. Edo Journal of Counselling, 2 (1).

Savickas, M. L. (1984). Career Maturity: The Construct Measurement. The Vocational Quarterly, 32 (4): 222-231.

Scholl, R. W. (2002). The structure of the self-concept.www.uri.edu/research/lrc/scholl.

Smart, J. C. and Pascarella, E.T. (1986). Self-concept development and educational degree attainment. International Journal of Higher education, 15 (Issue 1-2): 3-15.

Sneva, J. N. (2011).Exploring Career decision-making, self-Efficacy, Career maturity attitudes and racial identity attitudes of College students of Color. Unpublished PhD. Thesis. New York State University.

Strongman, K. T. (2006). Applying Psychology to Everyday life: A Beginner's Guide. England: John Wiley \& Sons Ltd.

Super, D. E, (1957). The Psychology of Careers. New York: Harper and Row Publishers.

Swann, W. B, Rentfrow, P.J. and Guinn, J. S. (2009). Self-Verification: The search for Coherence .http://wcr.sonoma.edu.vl.

Tambawal, M. U. (2001).Relationship among self-concept, self- other motivation and career maturity of Teachers in tertiary institutions in Sokoto State. Unpublished PhD. Thesis. Usman Danfodiyo University, Sokoto.

Tafarodi, R.W. and Swann, W. B. (2001). Two-dimensional self-esteem. Theory and measurement. Personality and Individual Differences. 31. 653-773.

Uba, A.and Olaniyi, G. B. (1990). Relative effects of Gender and family type on the Vocational Preference of School-going Adolescents in Oyo State. Nigerian Journal of Counselling and Development.5. 
Walker, A.S. and Sorce, P. A.(2009).Correlates of Job Satisfaction of early Career Employees in Printing and Publishing Companies. New York: Printing Industry Center.

Waugh R. S. (2000). Self-concept: Multidimensional ormulti-faceted, one-dimensional? Educational Research and Perspectives, 27 (2).

Weiner, B. (1986).An Attributional Theory of Motivation and Emotion. New York: SpringerVerlag.

Wigfold, A, Battle, A, Keller, L. B. and Eccles, J. S. (2000). Sex differences in Motivation, Self-concept, Career Aspiration and Career Choice: Implication for Cognitive Development. Journal of Career Development, 20 (130).

Williams, M. K. (2006).Issues in Educational Research and Statistics. researchmetods.net/kb copynote.php.

Wu, W. T. (1998). Vocational Interest and Career Maturity of male High school Students talented in math and science. Paper presented at $45^{\text {th }}$ Annual Convention of National Association of Gifted Children, Louisville, U. S. A.

Yaish, M. and Katz - Gerro, T. (2003). Higher education: Is more better? Gender differences in Labour market return to tertiary education in Israel. Oxford review of Education. 29 (4). 